\title{
Kwestia „razdielnorieczija” i śpiewu wielogłosowego w nauczaniu staroobrzędowców rosyjskich
}

\author{
Daniel Sawicki \\ infoechos@wp.pl
}

\begin{abstract}
Daniel Sawicki, Razdelnorechie and Polyphonic Singing in the Teaching of Russian Old Believers, Elpis, 16 2014: 201-209.
Abstract: This article discuses two very important problems concerning liturgical singing in Ruthenia. The first part of the article contains an analysis of the musical and linguistic phenomenon of razdelnorechie (also known as homonia). The author, presenting the issue from the Old Believers' point of view, tries to prove that elements of homonia in liturgical texts, contained in Old Believers songbooks, have not only been treated as a fillers of melisma (similar to latin tropus). Supporters of 'the old tradition' treated homonia and polyphonic services as sacred signs. The author in the second part of the article tries to find out the reasons of the Old Believers' negative attitude to polyphonic singing.
\end{abstract}

\begin{abstract}
Streszczenie: Artykuł zawiera rozważania na temat dwóch bardzo istotnych problemów dotyczących śpiewu cerkiewnego na Rusi. Autor w pierwszej części analizuje genezę dość unikalnego zjawiska muzyczno-językowego, określanego mianem „razdielnorieczija” (in. chomonii). Przedstawiając problem z punktu widzenia jednej z bardziej konserwatywnych grup wyznawców prawosławia - staroobrzędowców, stara się udowodnić, że elementy chomonii zawarte w tekstach liturgicznych, zawartykch w staroruskich śpiewnikach były przez nich traktowane nie tylko w kategorii wypełniaczy melizmatów, (podobne do łacińskich tropów). Zwolennicy „starych tradycji” zarówno chomonię, jak również wielogłosowe sprawowanie nabożeństw traktowali jako jeden ze znaków sakralnych. W drugiej części artykułu, autor stara się odpowiedzieć na pytanie, o przyczyny negatywnego stosunku staroobrzędowców do śpiewów wielogłosowych.
\end{abstract}

Keywords: liturgical singing of the Orthodox Church, znamenny chant, Old Believers

Słowa kluczowe: śpiew liturgiczny kościoła prawosławnego, znamienny śpiew, staroobrzędowcy

Staroruski monodyczny ${ }^{1}$ śpiew cerkiewny (tzw. znamiennyj raspiew $)^{2}$ jako jeden $\mathrm{z}$ większych fenomenów kultury duchowej „Starej Rusi” od dawien dawna wzbudza zainteresowanie teologów, muzykologów, historyków sztuki, a niekiedy także etnografów. Należy ubolewać jednak nad tym, iż ów drogocenny skarb, jakim dla duchowości prawosławia jest znamiennyj raspiew, dotychczas nie doczekał się w Polsce należytego opracowania. Dostępna literatura przedmiotu dostarcza czytelnikowi jedynie elementarnej wiedzy w tym zakresie. Co ciekawe, badający temat naukowcy zwykli skupiać się głównie na problemach natury historycznej³. Jeszcze mniejszym zasobem wiedzy nauka

\footnotetext{
Monodia - ( gr. $\mu \circ{ }_{0} \zeta=$ jeden, $\omega \delta \varepsilon=s ́$ piew), dosłownie śpiew przeznaczony dla jednego śpiewaka. Terminu tego używa się czasem w identycznym znaczeniu jak określenia monofonia, np. m. liturgiczna oznacza chorał. W istocie monodia odnosi się głownie do śpiewu solowego z towarzyszeniem instrumentalnym, który uprawiano już w średniowieczu we francuskiej balladzie, rondeau, virelais oraz we włoskim madrygale ballacie. Rodzaj ten rozwijał się również w renesansie, głownie jako pieśń $\mathrm{z}$ towarzyszeniem lutni, lub jako madrygał $\mathrm{z}$ towarzyszeniem klawikordu. Ten typ utworów przygotował grunt do powstania około 1600 roku monodii akompaniowanej z basso continuo, która stała się głównym środkiem wyrazu w kantacie operze i oratorium. Encyklopedia muzyki, red. A. Stankiewicz, Warszawa 2001, s. 567.

2 Termin ten w sposób szczegółowy wyjaśnia J. Gołos, Cerkiewny śpiew [w:] Encyklopedia Katolicka, T. III, kol. 1985, Lublin 1983, s. 19-21, por. W. Wołosiuk, Cerkiewny śpiew [w:] Religia - Encyklopedia, T. 2, Warszawa, red. nauk. T. Gadacz, B. Milerski, s. 396-398.

3 Zob.: W. Wołosiuk, Śpiew liturgiczny Kościoła prawosławnego w Polsce: teologiczna i muzyczna interpretacja jego wybranych elementów, Warszawa 1996, (rozprawa doktorska w ChAT); Rozwój wschodniosłowiańskiej monodii cerkiewnej $i$ jej zastosowanie w praktyce liturgicznej Polskiego Autokefalicznego Kościoła Prawosławnego - praca badawcza ChAT, Warszawa 2004.
}

polska dysponuje w odniesieniu do tradycji śpiewu cerkiewnego, jakie funkcjonują we wspólnotach staroobrzędowców ${ }^{4}$. Niniejszy artykuł, stanowi kontynuację moich rozważań na temat funkcjonowania $\mathrm{w}$ śpiewie liturgicznym na Rusi zjawiska, które literatura przedmiotu określa mianem „razdielnorieczija” lub chomonii ${ }^{5}$. Tym razem postaram się je omówić z punktu widzenia najbardziej konserwatywnej grupy wyznawców prawosławia - staroobrzędowców ${ }^{6}$.

W drugiej części swoich rozważań, zajmę się kwestią wprowadzenia do użytku liturgicznego śpiewów wielogło-

\footnotetext{
${ }^{4}$ Jedynymi pozycjami polskojęzycznymi odnoszącymi się do omawianej problematyki są prace E. Koschmiedera. Zob.: Przyczynki do zagadnienia chomonji w hirmosach rosyjskich, Wilno 1932; Teoria i praktyka rosyjskiego śpiewu neumatycznego na tle tradycji staroobrzędowców wileńskich, „Ateneum Wileńskie”, 1935, R. 10, s. 295-305, por. E. Iwaniec, Z dziejów staroobrzędowców..., dz. cyt., s. 172-173.

5 D. Sawicki, Staroje istinnorieczije i razdielnorieczijejako dwiegłówne epoki w dziejach śpiewu liturgicznego na Rusi od XI w. do XVII w., [w:] Z badań nad językiem i kulturą Stowian, red. P. Sotirov i P. Złotkowski, Lublin 2007, s. $169-178$.

${ }^{6}$ Staroobrzędowcy - zwani także starowiercami, przez Cerkiew prawosławną obraźliwie nazywani są także raskolnikami - pod tymi nazwami należy rozumieć tych wszystkich, którzy w XVII wieku odpadli od Cerkwi prawosławnej. Przyczyną rozłamu była poprawa ksiąg liturgicznych za patriarchy Nikona. Poddawani licznym represjom ze strony władz państwowych i cerkiewnych oraz pozbawieni wyższej hierarchii duchownej staroobrzędowcy, podzielili się na dwie główne grupy - tj. popowców (posiadających duchownych) oraz bezpopowców (nieuznających hierarchii duchownej), zaś te na szereg mniejszych sekt (ros. tołkow) różniących się między sobą pod względem dogmatycznym i obrzędowym. Zob.: Encyklopedja Kościelna, T. XXIII, wyd. M. Nowodworski, Warszawa 1899, s. 38-43, por. E. Iwaniec, $Z$ dziejów staroobrzędowców na ziemiach polskich XVII-XX w., Warszawa 1977.
} 
sowych. Na zakończenie postaram się odpowiedzieć na pytanie, skąd wziął się u staroobrzędowców negatywny stosunek do śpiewów wielogłosowych?

\section{Geneza kształtowania się zjawiska „razdielnorieczija” in. chomonii w śpiewie cerkiewnym na Rusi}

Kiedy po raz pierwszy usłyszałem u staroobrzędowców bezpopowców ich chomowoj śpiew cerkiewny, przyszły mi na myśl dwa zasadnicze pytania. Pierwsze, czy taka forma śpiewu jest prawidłowa? Drugie, czy wszechobecna chomonia w pełni odzwierciedla myśli teologiczne zawarte w tekstach liturgicznych? Kwestia zasadności stosowania chomonii, była pod koniec XIX wieku przedmiotem zażartej polemiki pomiędzy dwoma głównymi odłamami staroobrzędowców (popowcami i bezpopowcami), a co najważniejsze, wewnątrz samych bezpopowców ${ }^{7}$. Mimo, iż wielokrotnie poruszano ją $\mathrm{w}$ literaturze przedmiotu oraz dyskusjach polemicznych ${ }^{8}$ na łamach wydawanego na początku XX wieku w Kijowie czasopisma „Cerkownoje Pienije” do dziś pozostaje aktualną9. Do głębszego zainteresowania się nad problemem skłonił mnie fakt, iż śpiew chomowoj, przez staroobrzędowców nazywany śpiewem „na on" po dziś dzień pozostaje żywy w tradycji liturgicznej staroobrzędowców-pomorców, zamieszkujących terytoria dzisiejszej Litwy, Łotwy, Estonii oraz Polski ${ }^{10}$.

$\mathrm{Na}$ początek prześledzimy genezę kształtowania się tego unikalnego zjawiska muzyczno-językowego, które literatura tematu określa mianem "razdielnorieczija” (in. chomonii). Początki funkcjonowania "razdielnorieczija” w śpiewie cerkiewnym na Rusi należy wiązać z przemianami, jakie już pod koniec XIV wieku następowały w tekstach cerkiewnosłowiańskich przeznaczonych do śpiewania. Zasadniczo zmiany te polegały na zastępowaniu spółgłosek umieszczanych na końcu wyrazu samogłoskami (o, a, e, i). Co ciekawe, zmiany nie dotyczyły wówczas jeszcze tekstów przeznaczonych do recytacji, które praktycznie do końca $\mathrm{XV}$ wieku nie uległy wpływom chomonii.

\footnotetext{
Н. Никольская, «Сказание» инока Евфросина и певческая книжная справа XVII века, Санкт-Петербург 2008, s. 9.

O powadze problemu świadczy pismo żyjącego w XVII w. mnicha Efrozyma który tak oto skomentował ogólnie panujący styl śpiewu: „Śpiewem naszym tylko głos upiększamy, i znamienne kriuki nasze przekręcamy, zaś Święte słowa do końca po odwracane przeciw drukowanym i pisanym starym i nowym księgom”. Cyt. za: Ст. Смоленский, Примечания к азбуке Александра Мезени, Казань 1888, s. 34, (tłum. autor).

9 <Хомовое> или <наречное>, „Церковное Пение”, 1909, nr 8, s. 211-224, por. Г. Артамонов, О хомовом пении, „Труды Киевской Духовной Академии”, 1876, V. 1, s. 164, por. Е. Червякова, Традиции раздельноречного пения у старообрядиев поморского согласия [w:] Старообрядчество: история, культура, современность, Москва 2000, s. 486.

10 Б. Успенский, К вопросу о хомовом пении [w:] „Музыкальная культура средневековья”, Вып. 2, (Тезисы и доклады конференций), Москва 1991, s. 144.
}

Początkowo zastępowanie spółgłosek samogłoskami wynikało z faktu, że kopiści (od końca XIV w.) poczęli umieszczać znaki muzyczne nad spółgłoskami znajdującymi się $\mathrm{w}$ końcu wyrazu, których wykonanie było $\mathrm{z}$ wielu względów niemożliwe ${ }^{11}$. W tekstach "razdielnoriecznych" bardzo często spotyka się słowo chomo, z tego względu historycy śpiewu ten model nazwali chomoniq ${ }^{12}$. Poniższy przykład obrazuje zmiany tekstu, jakie nastąpiły z nastaniem razdielnorieczija:

\begin{tabular}{|c|c|}
\hline Istinnoreczije & Razdielnoreczije \\
\hline $\begin{array}{l}\text { Согрешихомъ, беззакон- } \\
\text { новахомъ, не оправдихомъ } \\
\text { предъ тобою, ни съблю- } \\
\text { дохомъ ни сътворихомъ } \\
\text { якоже заповеда намъ, но не } \\
\text { предажь нас до конъца оть- } \\
\text { чьскыи Боже. }\end{array}$ & $\begin{array}{l}\text { Согрешихом(о), беззакон- } \\
\text { новахом }(\text { о), не оправди- } \\
\text { хом(о) п(е)ред(о) тобою, ни } \\
\text { съблюдохом(о) ни с(о)тво- } \\
\text { рихом(о), якоже заповеда } \\
\text { нам(о), но не преда(и)ж(е) } \\
\text { нас(о) до конъ(е)ца от(е) } \\
\text { ч(е)скыи Боже. }\end{array}$ \\
\hline
\end{tabular}

Dążenie do „razdielnorieczija” było silne już w XIV wieku, a zjawisko początkowo dotyczyło jedynie wybranych śpiewników, i co najważniejsze, niewielu słów. „Razdielnorieczije" znalazło swoich zwolenników m.in. w środowisku śpiewaków nowogrodzkich. Jak podaje Nowogrodzki latopis z 1476 roku: „Tejże zimy niektórzy filozofowie (mianem tym określano śpiewaków cerkiewnych) zaczęli wykonywać zamiast Hospodi Pomituj, Ooospodi Pomiluj"'13. Z biegiem czasu chomonia niemal całkowicie wyparła $\mathrm{z}$ kriukowych ksiąg liturgicznych starą mowę prawdziwą, czego efektem były ostre spory śpiewaków dotyczące tego, która z redakcji tekstu liturgicznego jest prawidłowa. Jak każda nowinka, również „razdielnorieczije” posiadało $\mathrm{w}$ kręgach śpiewaczych, tak zagorzałych zwolenników, jak i przeciwników.

Od XV wieku następuje stopniowy upadek cerkiewnego szkolnictwa muzycznego na Rusi, a stało się tak z dwóch przyczyn. Po pierwsze, wskutek braku scentralizowanego szkolnictwa, gdzie szkoły prywatne prowadzone przez samych śpiewaków. Po drugie brakowało jednolitego programu nauczania. Każdy nauczyciel stosował własne metody, co niewątpliwie obniżało poziom przekazywanej wiedzy. Już pod koniec XV wieku, „razdielnorieczije” zaczęło dominować w liturgii. Jego szerzeniu sprzyjali sami hierarchowie, którzy niejednokrotnie osobiście redagowali nutowe księgi liturgiczne. Wśród zagorzałych zwolenników chomonii znaleźli się m.in. Wassian - arcybiskup Rostowa, Teodozjusz - arcybiskup nowogrodzki i pskowski ${ }^{14}$.

Wiek XVI zapoczątkował nowy okres w dziejach śpiewu cerkiewnego na Rusi. Wtedy to zaczęto wprowadzać do użytku wielogłosowość w sprawowaniu Służby Bożej, zaś wszechobecna $\mathrm{w}$ śpiewie chomonia wywołała istotne zmiany w tekstach liturgicznych i melodiach. Wprowadzanie

\footnotetext{
11 D. Sawicki, Staroje istinnorieczije..., dz. cyt., s. 169.

12 М. Бражников, Русская певческая палеография. Санкт-Петербург 2002, s. 47.

13 Д. Разумовский, Церковное пение в России. Опьт историкотехнического изложения, Москва 1867, s. 65

14 Д. Разумовский, Церковное пение..., dz. суt., s. 66.
} 
coraz większej liczby samogłosek do słowiańskiego tekstu spowodowało zniekształcenie melodii, przez co zatracały one swój pierwotny sens. Wtedy po raz pierwszy zaczęto mówić o potrzebie głębokiej reformy zarówno śpiewu cerkiewnego, jak i szkolnictwa kształcącego śpiewaków cerkiewnych $^{15}$. Taki stan rzeczy trwał nieprzerwanie do XVII wieku, kiedy to podjęto szereg reform, mających na celu zmianę zaistniałej sytuacji. Należy w tym miejscu przywołać dokonania I i II Komisji, z których pierwsza, rozpoczęła swoje prace $\mathrm{w} 1652 \mathrm{roku}^{16}$. Zasadniczym celem powołania obydwu Komisji była korekta nutowych ksiąg liturgicznych na starą mowę prawdziwą, co miałoby uczynić go „istinnoriecznym", czyli takim, jaki funkcjonował na Rusi do momentu wprowadzenia chomonii ${ }^{17}$. Wielka rola w dziele reformy przypadła osobie Aleksandra Miezienieca, który dodatkowo podjął się jak na owe czasy trudnego zadania ujednolicenia teorii śpiewu ${ }^{18}$.

\section{Chomonia i jej miejsce w nauczaniu staroobrzędowców}

Prace obydwu Komisji bez wątpienia zakończyłby się sukcesem, gdyby nie reformy ksiąg liturgicznych zaini-

\footnotetext{
5 „Тъмъ же протопопомъ, и старъйшимъ священникомъ, и со всъми священники и діяконы кійждо во своемъ городъ, по благословенію своего Святительства, избирати доблихъ и духовныхъ священниковъ и діяконовъ и діяковъ же, наученыхъ и благочестивыхъ, имущихъ въ сердцахъ страхъ Божій, могущихъ иныхъ пользовати, и грамоть бы, и чести и писати, горазди были. И у тъхъ священниковъ и діяконовъ учинити въ домъхъ училища, чтобы священники и діяконы, и вси православные Христіяне въ коемуждо градъ, предавали имъ своихъ дътей, въ наученіе грамоть, и на наученіе книжнаго писанія, и Церковнаго пънія и псалтирнаго пьнія налойнаго”. Сyt. za: Cтоглавъ, Санкт-Петербург 1997, s. 75.

16 Aleksandr Miezieniec tak oto relacjonuje wspomniane wydarzenia: „Соблагоизволися благочестивъйшему и въликому государю нашему, царю и великому князю Алексию Михайловичу, всея Великия и Малыя и Бълыя Россіи самодержцу: во преходящее время лъта 1655 о церковном пъніи знаменном пъніи предъль учинити, еже бы всякое пъніе было воистиннорьчном пьніи, вездъ во градъхъ и честныхъ обителехъ и сельхъ устроено равночинно, и доброгласно. И в тое время на тое божественное и святыя божія церкве дъло, его Царьскимъ повельніемъ во царствующемъ велицъмъ градъ Москве дидаскаловъ собрано къ тому знаменному устроенію разныхъ чиновъ отъ святыя божія церкве чиноначальниковъ и всякаго церковнаго чина избранныхъ людей 14 человъковъ. И от того времене учиниша от иностранныхъ окрестныхъ царствъ рати и брани, въ нихъ же многия царственныя и земския бъша великия дъла. Еще въ тьже времена гръхъ ради нашихъ приидъ и моровое повьтріе”. Суt. za: А. Мезенец, Извещение о согласнейщих пометах, изд. Ст. Смоленский, Казань 1888, s. 1.

17 Uczynienie śpiewu cerkiewnego „istinnoriecznym”, obok oczyszczenia go z elementów chomonii, miało obejmować również wprowadzenie do ksiąg liturgicznych tekstów jednakowych $\mathrm{z}$ tymi, przeznaczonymi do czytania, czyli przywrócenie tekstom ich „mowy prawdziwej”. Należałoby przy tym wspomnieć, iż nie były to jeszcze teksty liturgiczne z reformowane przez patriarchę Nikona. Kolejnym założeniem reformy było ujednolicenie melodii regułom nowo-zreformowanej notacji kriukowej. Na koniec Komisja miała opracować jednakowe dla całego państwa wzory ksiąg liturgicznych. Zob.: Ст. Смоленский, Примечания казбуке..., dz. cyt., s. 44.

18 D. Sawicki, Staroruski śpiew cerkiewny i funkcjonowanie jego wybranych form $w$ praktyce liturgicznej staroobrzędowców, Warszawa 2013 (rozprawa doktorska w ChAT), s. 74-88.
}

cjowane przez patriarchę Nikona przy czynnym poparciu cara Aleksego Michajłowicza. Nieumiejętnie przeprowadzone, zaowocowały Raskołom, który na wieki podzielił Cerkiew w Państwie Moskiewskim. Co więcej, reformy liturgiczne tylko, że podsyciły i tak już silne przywiązanie rzezy duchowieństwa i wiernych do dawnych porządków. Wyłonienie się nowej Cerkwi - staroobrzędowej, rozpoczęło polemikę na temat wielu ważnych kwestii obrzędowych, które z czasem rozgrywały się również wewnątrz niej samej. Jedna $\mathrm{z}$ takich kwestii, była niewątpliwie chomonia śpiewu, która jak udowodnimy, dzieliła samych staroobrzędowców.

U źródeł polemiki wokół śpiewu chomowego, stała zmiana obowiązujących na Rusi trendów estetycznych. Zjawisko to objęło wówczas niemal wszystkie dziedziny sztuki sakralnej na. Co ciekawe, uczeni zwykli wiązać zjawisko chomonii $\mathrm{z}$ innymi kwestiami mniemającymi z nią bezpośredniego związku (np. sposobem sprawowania nabożeństw). W rezultacie w świadomości naukowej wytworzyło się coś w rodzaju sztucznego związku. Zaczęto bowiem utożsamiać chomonię $\mathrm{z}$ wielogłosowością, zaś śpiew nariecznyj $\mathrm{z}$ jednogłosowością $\mathrm{w}$ sprawowaniu Służby Bożej ${ }^{19}$. Mimo to, przytoczony wyżej sposób postrzegania omawianego zjawiska, nie znajduje odzwierciedlenia w nauczaniu wyznawców „starej wiary”.

W swoich polemikach dotyczących śpiewu, staroobrzędowcy chętnie odwołują się do wybranych cytatów z Pisma Świętego oraz nauczania Ojców Kościoła. Znakomitym przykładem jest fragment Psalmu 46, 8, w którym psalmista nakazuje śpiewać Bogu „rozumnie” ${ }^{20}$. W myśl nauki Ojców Kościoła (św. Jan Złotousty) śpiewać rozumnie znaczy nie tylko wykonywać śpiew werbalny, lecz także pobudzać myśli ku głębszemu zrozumieniu tego, co się śpiewa ${ }^{21}$. Czy zatem chomonia w śpiewie jest zgodna z nauką Ojców Kościoła? Staroobrzędowcy bezpopowcy powiedzą, że tak, ponieważ rozrost melizmatów w melodiach cerkiewnych sprzyja pokucie i kontemplacji, i tym samym przybliża człowieka do Boga ${ }^{22}$. Co więcej, niemal każdy bezpopowski podręcznik do nauki śpiewu chwali śpiew „razdielnoriecznyj” jako ten najstarszy (przyjęty przez Księcia Włodzimierza z Bizancjum), a zatem najbardziej prawidłowy ${ }^{23}$. Jednak wnikliwa analiza dzieł pierwszych pisarzy staroobrzędowych XVII wieku, zmusza nas do głębokiego zastanowienia się nad sensem funkcjonowania chomonii w śpiewie. Wzmianki, mówiące o konieczności wykorzenienia chomonii znajdziemy m.in. w pismach protopopa Awwakum. W jednym z nich czytamy: „Teraz w wielu cerkwiach śpiewają pieśni, a nie boski śpiew, reguły mają łacińskie, machają rękami, kiwają głowami, tupią nogami, tak jak to czynią łacinnicy

\footnotetext{
19 Б. Успенский, К вопросу о хомовом..., dz. суt., s. 146.

20 Śpiewać rozumnie tzn. przemyślanie, godnie Boga. - Zob.: Толковая Библия или комментарии на все книги Св. писания Ветхого и Нового Завета, Петербург 1904-1913, изд. II, Стокгольм 1987, T. I, s. 227.

21 Рor. Е. Зигабенъ, Толковая Псалтирь, Киев 1907, s. 373.

22 Б. Кутузов. Церковная реформа XVII века, Москва 2004, s. 493.

23 Сборник знаменных песнопений, включающий Азбуку знаменных песнопений, Москва 1984, s. 314.
} 
przy wtórze organów"24. Mimo, iż Awwakum bądź co bądź, tolerował chomonię $e^{25}$, to w jednym ze swoich pism stwierdza: „nariecznyj śpiew ja sam żyjąc w Moskwie do epidemii dżumy słyszałem" ${ }^{26}$. Wobec braku dostatecznych powodów ku temu, by nie dać wiary słowom Awwakuma, cytowany fragment może świadczyć o wzajemnym przenikaniu się tradycji naonnoj i nariecznoj ${ }^{27}$. Wiele wskazuje na to, iż przeważająca część sympatyków „starej wiary”, była zwolennikami śpiewu wykonywanego na starą mowę prawdziwą.

W 1651 roku miał w Moskwie miejsce Sobór, który podjął uchwały mające na celu m.in. uporządkowanie śpiewu. Pierwszym krokiem ku osiągnięciu zamierzonego celu, miało być wprowadzenie jedinogłasija w sprawowaniu Służby Bożej. Kwestia wykorzenienia chomonii, mimo, iż była wprawdzie podejmowana, to wciąż pozostawała nie rozwiązana ${ }^{28}$. Co więcej, uchwały soborowe nie tylko nie położyły kresu różnorodności form sprawowania nabożeństw, lecz także nie przyczyniły się do jej wykorzenienia z muzycznych ksiąg liturgicznych. Sama chomonia zyskiwała sobie coraz to nowych zwolenników w osobach staroobrzędowców, wywodzących się ze stronnictw przeciwnych Awwakumowi ${ }^{29}$. W rozwiązaniu tejże kwestii nie pomogło także wstąpienie na tron patriarszy metropolity nowogrodzkiego Nikona. Nowo wybrany patriarcha skupiał swoją uwagę głównie na reformach tekstów liturgicznych i obrzędowych, toteż kwestia śpiewu niestety musiała zejść na dalszy plan ${ }^{30}$.

Pragnienie uporządkowania śpiewu cerkiewnego i zaprowadzenia $\mathrm{w}$ tekstach liturgicznych starej mowy prawdziwej nie było obce Awwakumowi. Protopop, mimo, iż w swoim czasie przebywał w więzieniu w Pustoziersku, uważnie śledził bieżące wydarzenia w Moskwie. Jak podają źródła, Awwakum, dowiedziawszy się o tym, iż jeden z jego zwolenników - pop Stefan sympatyzuje chomonii napisał $\mathrm{z}$ więzienia do niego pismo, w którym ostro skrytykował jego przekonania ${ }^{31}$. W celu podparcia prawdziwości swoich

\footnotetext{
24 Cуt. za: Автобиография или житие протопопа Аввакума, tekst dostępny na: http://www.canto.ru/index.php?menu=public\&id=source. abbakum (tłum. autor) [02.03.2013].

25 „Zapomnieli małoduszni chrześcijanie kriukowy ustaw, zaprzedając się zgubnemu dla duszy śpiewowi nariecznomu". Cyt. za: A. Преoбраженский, Культовая музыка в России, Ленинград 1924, s. 35, (tłum. autor).

26 Mowa tu o latach 1654-55. Суt. za: Ст. Смоленский, Примечания казбуке..., dz. cyt., s.33-38.

27 Jako przykład zjawiska wzajemnego przenikania się obu tradycji śpiewu E. Czerwiakowa podaje, iż we wspólnotach popowców w początkowej fazie rozłamu funkcjonowała chomonia, która w XVIII wieku została wyparta przez nową mowę prawdziwą.

28 П. Смирнов, Внутренние вопросы в расколе в XVII веке, СанктПетербург 1898, s. 210.

29 С. Быстров, Взглядь протопопа Аввакума на <хомовое> пение, „Церковное Пение”, 1909, nr 4-5, s. 136.

30 Н. Каптерев, Патриарх Никон и иарь Алексей Михайлович, Т. I, Сергиев Посад 1909, s. 134

31 „...Но токмо, отче имъю на тя, яко держиши ученіе не по преданію отеческому и гнушаешися единогласнаго пънія. Се бо есть не православно, но зъло богопротивно. Златоустъ насъ побуждаетъ единогласно пъти во церкви: ищи ево правоученіе в Бесъдахъ апостольскихъ, по главамъ найдешъ, и егда прочтешъ, тогда сам себе постыдишася... И единогласно пълъ лътъ 3 двадцатъ, и нынъ пою
}

tez, protopop powoływał się na autorytet Św. Jana Złotoustego, Ojców Soboru Stu Rozdziałów oraz swoje własne doświadczenia związane ze śpiewem ${ }^{32}$. W ostateczności Awwakum wybaczył swojemu przyjacielowi takie postępowanie, sam poprosił o wybaczenie za zbyt ostre słowa ${ }^{33} \mathrm{i}$ od tego czasu miała między nimi miejsce ożywiona wymiana korespondencji ${ }^{34}$.

Entuzjaści chomonii nie szczędzili słów krytyki pod adresem Awwakuma. Ten zaś, jak przystało na prawdziwego pasterza, starał się łagodzić spory, wskazując na różne bezsensowne wtręty w śpiewie np. ananejki $i^{35}$. W jednym ze swoich listów pisał: „A śpiew cerkiewny ja sam, że czytam i śpiewam - jednogłosowo i na mowę prawdziwą, śpiewam: kriuki te w przekładach tych dla mnie bezwartościowe i Nienajki, te psie niepotrzebne są?"36. Nie wiadomo, co Awwakum miał na myśli, mówiąc o jednogłosowości, czy chodziło mu o jedinogłasije w sposobie sprawowania nabożeństw, czy też wykonywany unisono znamiennyj raspiew. Zwykł Awwakum chwalić się także swoimi umiejętnościami śpiewu $\mathrm{z}$ pamięci, $\mathrm{w}$ jednym $\mathrm{z}$ listów skierowanym do rodziny z miejsca zsyłki - klasztoru św. Mikołaja w Ugrieszy tak oto żali się: „Ksiąg nie mam ani wiersza” ${ }^{”}$. Dalej przechwala się mówiąc „z pamięci śpiewam Bogu memu, słowo Boże w moich ustach"38. Kolejnym zarzutem protopopa skierowanym przeciwko ówczesnym śpiewakom, był brak jednolitej teorii śpiewu oraz wszechobecna swoboda w interpretacji kriuków ${ }^{39}$. Poglądy Awwakuma zyskały szerokie poparcie nie tylko $\mathrm{w}$ kręgach carskich, lecz także wśród hierarchów cerkiewnych i szerokiej grupy ducho-

Богу моему дондеже есмь единогласно. Понеже бо при царғ Иване и при Макаріи митрополить, таможе бысть и Гурій архіепископъ казанский на соборъ, и тогда грамоты изданы о единогласномъ пьніи. И наръчныя ирмосы видъхъ своима очима старобытныя, тогда же писаны. И до мору, приходя къ Казанской, прежде ссылки даурской, по нихъ многажды пълъ со священномученикомъ Даніиломъ с костромскимъ протопопомъ, пострадавшимъ за правовъріе отъ Никона волка и адова пса". Суt. za: Аввакум, Послание к священнику Стефану [w:] Материаль для истории раскола за первое время его существования, обр. Н. Субботин, Т. V, Москва 1879, s. 215-216.

32 П. Смирнов, Внутренние вопросы..., dz. суt., s. 211.

33 „Ну простите меня; я предъ вами согрьшилъ, прогньвалъ вашу святыню”. Суt. za: Аввакумъ, Послание к священнику..., s. 217.

34 С. Быстров, Взглядъ протопоna..., art. cyt., s. 137.

35 „Ananejnki” i „chabuba” - formuły melodyczne melizmatycznego charakteru nie posiadające żadnego związku z tekstem liturgicznym. Ich rola polegała m.in. na uzupełnianiu niezbędnej ilości sylab w danej linijce wierszowej tekstu słowno-muzycznego. R. Łużny, Staroobrzędowcy i problemy muzykologiczne Dawnej Rusi [w:] Musica Antiqua Europae Orientalis, T. VII, Bydgoszcz 1985, s. 89, por. И. Гарднер, Богослужебное пение русской православной церкви, Т. I, Москва 2004, s. 250-251.

36 П. Смирнов, Внутренние вопросы..., dz. суt., s. 212.

37 Awwakum mógł tu mieć na myśli zbiorek wierszy duchownych (cs. духовных стихов).

38 Cyt. za: Awwakum, List do rodziny [w:] Żywot protopopa Awwakuma przez niego samego nakreślony i wybór innych pism, przeł. W. Jakubowski, Wrocław-Warszawa-Kraków-Gdańsk 1972 ,s. 316.

39 „И в старыя времена иные фиты всъ выпъвають, а иные и отлагаютъ, да то нътъ ничево: рьчь бы была чиста, и права и непорочна. А знамя иной знаменное поетъ, а иной тотъ же стихъ строками поютъ; а кто не умъетъ всему, и онъ говоромъ говорилъ. Да однако, слава Богу; токмо бы не сумъсицею молить.... А гдъ не единогласно пъніъ и не наречно: тамъ какое посльдованіе слову разумно бываетъ?". Суt. zа: Аввакум, Послание к неизвестному лииу [w:] Материалы для истории..., Т. V, s. 222. 
wieństwa. Dla przykładu, sam zagorzały zwolennik starych porządków - protopop Stefan Wonifatiew oprócz zakazu wielogłosowości nabożeństw wprowadził w swojej parafii śpiew nariecznyj. Śladem Wonifatiewa poszedł protopop Iwan Nieronow ${ }^{40}$, który de facto należał do tego samego ugrupowania, co Awwakum i Wonifatiew ${ }^{41}$.

Niemniej konserwatywni w swoim podejściu do problematyki śpiewu okazali się: diakon Aleksander ze Starodubia oraz staroobrzędowcy bezpopowcy znad Wygu ${ }^{42}$. Z licznie zachowanych rękopisów muzycznych wynika, iż staroobrzędowcy pomorscy od zawsze hołdowali chomonii. Przeciwnicy Andrzeja Denisowa przy każdej nadarzającej się okazji zwykli mu wypominać jego dwuznaczny stosunek do chomonii. Staroobrzędowcy moskiewscy zarzucali Andrzejowi to, iż z jednej strony śpiew „istinnoriecznyj” nazywa „anielskim”, z drugiej zaś jego wspólnota twardo trzyma się chomoni. Jeżeli Denisow rzeczywiście był zwolennikiem obecności w śpiewie starej mowy prawdziwej, to brak jakiegokolwiek działania w tym zakresie należy rozpatrywać w kategorii obawy o utratę pozycji przełożonego pustelni Wygowskiej. Jednak prawdziwy „wyłom” w przywiązaniu bezpopowców do chomonii uczynił Iwan Aleksiejew ze Starodubia, który nie tylko, że sam praktykował śpiew „istinnoriecznyj”, lecz również pisał liczne apologie w jego obronie. Zanim zmarł w 1776 roku, zdążył poprawić „na riecz” wiele ksiąg liturgicznych ${ }^{43}$. Podobny stosunek do "razdielnorieczija” wykazywała grupa moskiewskich bezpopowców, a szczególnie zmarli w latach 1846-1847 Andriejan Siergiejew oraz nastawnik molenny moskiewskiej Iwan Wasiliew Onisimow. Pierwszy zostawił po sobie traktat krytykujący chomonię, drugiemu zaś przypisuje się poprawienie obszernego „Cyklu” muzycznych ksiąg liturgicznych ${ }^{44}$. Mimo iż do końca XVI wieku „razdielnorieczije” było ogólnie panującą formą śpiewu na Rusi, już w tamtym okresie wywoływało wiele sporów w kręgach śpiewaków cerkiewnych.

Oczyszczenie melodii z elementów chomonii stało się głównym celem prac I i II Komisji, na co zwrócił uwagę znawca śpiewu St. Smoleński. W swojej przedmowie do wydania Azbuki Aleksandra Miezienieca pisze: "Słyszący śpiew bezpopowców śpiewających „na on" z zachowaniem wszelkich ananajek, chebuwe byli porażeni wymową tekstu słyszanych melodii”. Jak słusznie zauważył Smoleński, dźwięk, ъ dla którego praktycznie nie ma litery w alfabecie cerkiewnosłowiańskim był wymawiany przez tych śpiewaków twardo, w jednakowy sposób zamieniano litery e, $\mathbf{b}$ oraz b bez rozróżnienia akcentu w słowie oraz wskazania na twardość czy miękkość dźwięku ${ }^{45}$. Takie prostoduszne podejście do problematyki wymowy zaobserwowane u bezpopowców, mogło powodować u pos-

\footnotetext{
40 „Они первее уставиша въ своихъ церквахъ единогласное и согласное пение”. Суt. za: А. Бороздин, Протопопь Аввакум. Очеркъ истории умственной жизни русскаго общества въ XVII веке, СанктПетербург 1900, s. 9.

41 Tamże, s. 17.

42 Поморские ответы, Москва 1911, k. 346-348.

43 Г. Артамонов, О хомовом пении..., dz. cyt., s. 165.

44 Tamże, s. 166-167.

45 Ст. Смоленский, Примечания к азбуке..., dz. cyt., s. 37.
}

tronnych słuchaczy pewien chaos ${ }^{46}$. Z tego głównie względu, zdaniem badacza, przeprowadzona w XVII wieku reforma śpiewu była potrzebna i w pełni zrozumiała ${ }^{47}$. Zdanie Smoleńskiego podzielił jemu współczesny, badacz dziejów Raskołu - A. Borozdin. Na podstawie analizy językowej chomowych ksiąg liturgicznych udowodnił, iż w śpiewie chomowom wymowa poszczególnych słów tekstu liturgicznego zmieniała się do tego stopnia, że stawały się niezrozumiałe $^{48}$. Natomiast analiza muzykologiczna, jaką przeprowadził Ks. D. Razumowski, dowiodła, iż zastosowanie chomonii w znaczący sposób zmienia rytmikę danej melodii $^{49}$. Kolejnym istotnym problemem, jakiemu A. Borozdin poświęca uwagę, była panująca wówczas na Rusi różnorodność szkół kształcących śpiewaków oraz brak jednolitego programu nauczania. Gdy dołożyć do tego fakt, iż absolwenci różnych szkół byli w większości ze sobą skłóceni, wyłania się nam obraz wielkiego bałaganu ${ }^{50}$.

Aby móc choć po części przybliżyć się do poznania prawdy, należy ponownie zagłębić się w historię śpiewu cerkiewnego. Cel ten, zdaniem Ks. D. Razumowskiego można osiągnąć jedynie na drodze studiów źródeł kronikarskich oraz analizie zachowanych rękopisów muzycznych. Pierwszym miastem, w którym rozwijał się śpiew cerkiewny, według przekazu zawartego w Stiepiennoj Knigie, był Kijów ${ }^{51}$. O prawdziwości tego przekazu był przekonany Aleksandr Miezieniec. W przedmowie do swojego dzieła: „Izwieszczenije o sogłasniejszich pomietach" stwierdził, iż to właśnie z Kijowa pochodzili należycie wykształceni śpiewacy, którzy poprzez Nowogród rozpowszechniali „dobre” wzorce śpiewu, czyli śpiew „istinnoriecznyj” ${ }^{52}$.

Nie da się zrozumieć sensu „razdielnorieczija” oraz uzasadnić tego, dlaczego staroobrzędowcy darzą je tak wielkim szacunkiem bez odniesienia się do istoty omawianego problemu. Cel ten, zdaniem współczesnej badaczki tematu - E. Czerwiakowoj można osiągnąć poprzez rozróżnienie dwóch modeli modlitewnego spotkania człowieka ze światem Boskim. W jednym $\mathrm{z}$ nich słowo śpiewane jest skierowane ku światu zewnętrznemu, w drugim zaś ku Bogu ${ }^{53}$. Dlatego też może ono wychodzić poza oddziaływanie zewnętrzne. „Razdielnorieczije”, zdaniem E. Czerwiakowoj, winno być rozpatrywane $\mathrm{w}$ kontekście drugiego modelu, jako rodzaj „modlitwy Duchem”. Stanowi ono organiczny atrybut formy takiego przekazu, jaki nie zna reliktów archaicznej wymowy ${ }^{54}$. Badaczka słusznie zauważa również

\footnotetext{
46 Н. Парфентьев, Древнерусское певческое искусство в духовной культуре Российского Государства XVI-XVII вв., Свердловск 1991, s. $189-190$.

47 Ст. Смоленский, Примечания к азбуке..., dz. cyt., s. 38

48 А. Бороздин, Протопопь Аввакум..., dz. cyt., s. 10.

49 Д. Разумовский, О знаменном роспеве [w:] Круг иерковнаго древняго знаменнаго пения в шести частях. Иждивением потомственнаго почетнаго гражданина Арсения Ивановича Морозова, СанктПетербург 1884, Ч. I, s. VII.

50 А. Бороздин, Протопопь Аввакум..., dz. суt., s. 8.

51 Д. Разумовский, Церковное пение..., dz. суt., s. 57.

52 А. Мезенец, Извещение о согласнейших..., dz. cyt., s. 6, por. Макарий [М. Булгаков], История Русской Церкви, Санкт-Петербург 1888 , T. XI, s. 169

53 Badaczka ma na myśli śpiew wielogłosowy.

54 Е. Червякова, Традиции раздельноречного..., dz. суt., s. 487.
} 
to, iż „razdielnorieczije” stanowi dla staroobrzędowców swoiste sacrum porównywalne do kanonicznej architektury cerkiewnej i ikonografii. Wprowadzenie do użytku śpiewu „nariecznogo", zdaniem jego przeciwników, naruszyło harmonię tekstu i melodii. Co więcej, reforma śpiewu poniosła za sobą swoiste zakłamanie, jakoby śpiew „chomowoj” był niedoskonały. Zdania tego nie podzielali i nie podzielają staroobrzędowcy bezpopowcy, dla których tzw. „naonnoje pienie" nie tylko, że stanowi kontynuację staro-bizantyjskich tradycji śpiewu, lecz jest także istotnym elementem ich tożsamości religijnej.

Śpiew cerkiewny w rozumieniu staroobrzędowców winien być przede wszystkim formą spotkania człowieka $\mathrm{z}$ Bogiem, a nie człowieka z człowiekiem. $\mathrm{Z}$ tego względu ważnym jest obiektywne zrozumienie sensu wyśpiewywanych tekstów. Zwolennicy „starych tradycji” zarówno chomonię, jak również wielogłosowe sprawowanie nabożeństw traktowali jako jeden z sakralnych znaków $w^{55}$. Dla części wyznawców starej wiary nie do przyjęcia było wprowadzenie przez Nikona śpiewu "nariecznogo" i co najważniejsze, obcych „ruskiemu duchowi” śpiewów wielogłosowych.

Mimo, iż duch czasu (zmiany w wymowie, melizmatyce) stale przenika w tę zamkniętą sferę, jaką jest śpiew „razdielnoriecznyj”, to znajdują się zatwardziali w swoim przywiązaniu do chomonii starcy, którzy zacięcie bronią tegoż elementu „starego”. Już samo wprowadzenie do śpiewu liturgicznego „nowej mowy prawdziwej” nie obyło się bez trudności. Nie ulega wątpliwości, iż przedsięwzięcie to stało się jednym z fundamentów przyszłego rozłamu na łonie Cerkwi rosyjskiej. Raskoł w swojej końcowej fazie rozwoju obok językowej objął również muzyczną stronę prawosławnego nabożeństwa ${ }^{56}$.

\section{Problem śpiewów wielo- głosowych w nauczaniu staroobrzędowców}

Wszystkie stronnictwa staroobrzędowe łączyła jednakowa - negatywna ocena śpiewów wielogłosowych (cs. partiesnoje pienije ), które to ich zdaniem, nie pasowały do ówczesnej duchowości. Ten swoisty konflikt epoki, którego jedną ze stron stali się, wstrząsnął życiem kulturalnym Rusi Moskiewskiej 2-giej połowy XVII wieku ${ }^{57}$. Nie bez znaczenia było zdanie protopopa Awwakuma, który uważał, że: „Bardzo wstrętny Bogu jest dzisiejszy śpiew”58. Zastępowanie starych jednogłosowych melodii innymi (jednogłosowymi melodiami greckimi, kijowskimi i bułgarskimi oraz kompozycjami wielogłosowymi), było podyktowane chęcią wyjścia naprzeciw skierowanym ku zachodowi gustom

Б. Успенский, Раскол и культурный конфликт XVII века [w:] Избранные Труды, Москва 1996, Т. I, s. 504.

56 М. Бражников, Русская певческая..., dz. суt., s. 48-49.

57 Т. Владышевская, Музыкальная культура Древней Руси, Москва 2006, , s. 96

58 Суt. za: Аввакум, Послание к некоей Маремяне Федоровне [w:] Материалы для истории..., Т. V, s. 197. słuchaczy. Zarówno powrót do „starej mowy prawdziwej”, jak i odejście od praktyki wielogłosowości w sprawowaniu Służby Bożej, należy potraktować jako początek konwencjonalnego stosunku do znaków sakralnych ${ }^{59}$.

Pierwsze próby wprowadzenia na szeroką skalę śpiewów wielogłosowych podjął patriarcha Nikon, jeszcze jako metropolita nowogrodzki. Zwolennicy jego reform chętnie podkreślają, iż nie czynił tychże zmian $\mathrm{w}$ śpiewie samowolnie. Nikon, podobnie jak jego poprzednik - patriarcha Józef, w ważnych kwestiach dotyczących obrzędowości zasięgał rady patriarchy konstantynopolitańskiego ${ }^{60}$. Na ile Nikon liczył się ze zdaniem Konstantynopola, pozostaje kwestią dyskusyjną. Wymaga bowiem przeprowadzenia dogłębnej analizy korespondencji wymienianej pomiędzy obydwoma patriarchatami.

Staroobrzędowcy chętnie podkreślają tezę, iż: „Cerkiew to dom modlitwy a nie teatr"61. Tezę tą rozwinął współczesny badacz tematu - B. Kutuzow, który uważa, iż reformatorzy XVII wieku bardzo dobrze rozumieli, że szeroka melizmatyczność śpiewu „razdielnoriecznogo" o wiele bardziej odpowiadała ówczesnej duchowości, aniżeli komponowany „na zachodnią modę” śpiew wielogłosowy, którego zagorzałym miłośnikiem byli Nikon i car Aleksy Michajłowicz ${ }^{62}$. Zgoła odmienne zdanie na ten temat wykazał XIX -wieczny znawca tematu - staroobrzędowiec S. Bystrow. Śpiew bezpopowców, jego zdaniem, powinien rozwijać się w kierunku wytyczonym przez protopopa Awwakuma.

Sukcesywne wprowadzanie do praktyki liturgicznej wielogłosowych melodii greckich i kijowskich ${ }^{63}$, jak również zachodniej notacji muzycznej, już samo w sobie, stanowiło zerwanie $\mathrm{z}$ dotychczas obowiązującymi na Rusi kanonami, co siłą rzeczy musiało wpłynąć na diametralną zmianę postrzegania śpiewu cerkiewnego. Czynnikiem sprzyjającym upowszechnieniu śpiewów wielogłosowych był patronat patriarszy nad muzykami, których rzesze napływały wówczas do Moskwy $\mathrm{z}$ terytorium południowo-zachodniej Rusi ${ }^{64}$. Pierwsze informacje o masowym osiedlaniu się śpiewaków kijowskich w Państwie moskiewskim pochodzą z 1652 roku. Jeden z dokumentów, opublikowany przez W. Undolskiego mówi o przybyciu do Moskwy śpiewaków z Kijowa: Jakuba Ilina, Piotra Iwanowa, Iwana Sylwestrowa, Mychajła Osipowa, Romana Pawłowa, Grzegorza Iwanowa, Stiepana Timofiejewa, Iwana Niektariewa ${ }^{65}$. Przywiezione przez nich wielogłosowe melodie cerkiewne były doskona-

\footnotetext{
59 Е. Червякова, Традиции раздельноречного..., dz. cyt., s. 503.

60 М. Зызыкин, Патриарх Никон. Его государственные и канонические идеи, Варшава 1931, Ч. 3, s. 210-211.

61 В. Смирнов, Падение Третьего Рима. Духовные основы возрождения Русского Православного Царства, Санкт-Петербург 2008, s. 45.

62 Б. Кутузов. Церковная реформа..., dz. суt., s. 493.

63 Makarij [M. Bułgakow], Макарий [М. Булгаков], История Русской Церкви..., Т. XI, dz. суt., s. 170.

${ }_{64}$ Н. Соболев, Мелодчческое (одноголосное) пение Православной Русской Церкви, „Богословский Вестник”, Т. 3, nr 9, s. 101-102, por. М. Антонович, Українські співаки на Московщині в XVII cm. [w:] Mиsica Sacra. Збірнык статей з історії украӥнської иерковної музики, Львів 1997.

65 В. Ундольский, Замечания для истории иерковного пения в России, Москва 1846, s. 16.
} 
łym narzędziem w walce z wpływami Kościoła unickiego ${ }^{66}$. Ich wprowadzeniu do liturgii pod koniec XVI i na początku XVII wieku patronowały bractwa prawosławne ${ }^{67}$. Szczególne zasługi w dziele upowszechniania śpiewu wielogłosowego odegrały bractwa: łuckie, wileńskie, mohylewskie, kijowskie oraz lwowskie ${ }^{68}$. Z czasem Moskwa wykształciła własnych specjalistów, zajmujących się śpiewem wielogłosowym. Obok wspomnianego już wcześniej Mikołaja Dyleckiego działał także diakon Ioanikij Korieniew, który zestawił własną gramatykę śpiewu, dziesięć lat później uzupełnioną przez N. Dyleckiego ${ }^{69}$. Ten wielki entuzjasta śpiewu partesnego poddawał ostrej krytyce wszystkie obowiązujące wcześniej na Rusi formy wielogłosowości, w tym także tzw. strocznoje pienije, które uważał za śpiew „niemiły Bogu"70. Wielkie zasługi w dziele przekładu staroruskich melodii na kwadratową notację kijowską (cs. kijewskoje znamia) miał także Tichon Makariewskij ${ }^{71}$.

Mimo przychylności władz cerkiewnych, wobec rozmaitych nowinek $\mathrm{w}$ dziedzinie śpiewu liturgicznego, melodie wielogłosowe wciąż wywoływały wielkie zgorszenie wśród przywiązanych do starych tradycji Rusinów. Fakt ten przemilczał z wiadomych względów biograf Nikona - I. Szuszerin. Zauroczonym bogactwem melodycznym wprowadzanych przez Nikona śpiewów tak oto pisał: „Przewielebny metropolita Nikon najpierw polecił w Soborowej Cerkwi śpiewy greckie i kijowskie wykonywać z należytą pilnością, i na chwałę zebrał klirosy (chóry) złożone $\mathrm{z}$ przedziwnych śpiewaków o pięknych głosach, śpiew był uduchowiony w przeciwieństwie do dźwięku organów - nie posiadających ducha. Takiego śpiewu jak u metropolity Nikona u nikogo nie było"72. Jako ciekawostkę pozwolę sobie podać fakt, iż Nikon gardził wszelką muzyką instrumentalną, dlatego też karcił bojarów, którzy byli nią wielce zafascynowani. Szczególnie nienawidził organów, jako przejawu wpływów polskich ${ }^{73}$. Jak podaje Szuszerin, ilekroć Nikon jeszcze jako metropolita przybywał do Moskwy, to sprawował w pałacowej cerkwi specjalne nabożeństwa dla członków rodziny carskiej, podczas których śpiewali nowogrodzianie. Aleksy Michajłowicz miał być pełen podziwu dla piękna tychże melodii oraz zaprowadzonych

\footnotetext{
66 И. Гарднер, Богослужебное пение..., Т. II, dz. суt., s. 82.

67 И. Вознесенский, Осмогласные роспевы трех последних веков Православной Русской Церкви, Т. І, Киевский роспев, Киев, 1888, s. 9. 68 Tamże, s. 30.

69 We wstępie do dzieła Ioanikija Korieniewa czytamy: „Книга глаголемая Мусикия, изданная прежде в царствующем граде Москве о пении божественном ради благочиния церковнаго от любомудрых художников на посрамление бездушных висканий органных, ими же мнятся хвалу приносити богу во храме господни, и на трестрочное и демественное пение великороссийское в лето от создания мира 7179-го. РГБ, ф. 173. III, nr 154, k. 1. \{Российская Государственная Библиотека, Москва. Собрание по временному каталогу библиотеки Московской Духовной Академии

70 W. Wołosiuk, Wschodniosłowiańscy kompozytorzy muzyki cerkiewnej od XVII do 1. połowy XX wieku i obecność ich utworów w nabożeństwach PAКР, Warszawa 2005, s. 39.

71 И. Вознесенский, Осмогласные роспевы..., dz. cyt., s. 31.

72 И. Шушерин, Известие о рождении и воспитании и житии святейшего Никона, патриарха Московского и всея России, Москва 1871s. 21, (tłum. autor).

73 М. Зызыкин, Патриарх Никон..., Ч. 3, dz. cyt., s. 45.
}

przez Nikona porządków w sprawowaniu nabożeństw. Car chętnie zasięgał rady metropolity w sprawach spornych odnośnie obrzędowości, a Nikon potrafił doskonale wykorzystać to zaufanie do osiągnięcia własnych celów ${ }^{74}$. Na początek zasugerował Aleksemu Michajłowiczowi odgórne wprowadzenie w całej Rosji do liturgii śpiewu opartego na wzorcach nowogrodzkich ${ }^{75}$. Zamierzonego celu jednak nie osiągnął z prostego względu, a mianowicie zakrojone na taką skalę przedsięwzięcie było nie do przeprowadzenia. Nikon nie porzucił jednak marzeń o unifikacji śpiewu, i już jako patriarcha dbał o rozpowszechnianie tychże śpiewów $\mathrm{w}$ innych diecezjach, zachęcając do tego miejscowych biskupów $^{76}$. Śpiew kijowski stanie się ogólnie panującym już pod koniec XVII wieku ${ }^{77}$. O ile unifikacja śpiewu Nikonowi nie powiodła się, o tyle patriarcha dokonał czegoś więcej, a mianowicie doprowadził do zaistnienia w Rosji różnorodności melodycznej i stylistycznej, której jak uważa ks. J. Wozniesieński, do tej pory nie było. Wraz z ograniczaniem wykonywania $\mathrm{w}$ świątyniach melodii znamiennago raspiewa, skróceniu uległ czas trwania nabożeństw, podczas których wykonywano jeden, lub kilka określonych typów melodii (cs. raspiewow) ${ }^{78}$.

Wprowadzenie do użytku liturgicznego nowych melodii cerkiewnych było częścią o wiele bardziej złożonego procesu, jaki rozpoczął się na przełomie XVI i XVII wieku. Chodzi tu mianowicie o zmianę postrzegania szeroko pojmowanej „sztuki”, która jak słusznie zauważył W. Byczkow, powoli przestawała pełnić rolę aktu modlitewnego dążenia do jedności z Bogiem. Coraz częściej traktowano ją w kategorii rzemiosła, w którym duchowość musiała ustąpić miejsce walorom artystycznym ${ }^{79}$. Nie ulega wątpliwości, iż wykonywanie melodii bułgarskich, kijowskich i greckich niosło za sobą swoistą świeżość intonacji, jak również były one bliskie pieśni ludowej. W melodiach starych raspiewow, które na przestrzeni wieków ulegały licznym przemianom świeżość ta została $\mathrm{w}$ jakimś stopniu zatracona ${ }^{80}$. Nowego ducha w stary znamiennyj raspiew tchną dopiero staroobrzędowcy, którzy staną przed trudnym, ale jakże szczytnym zadaniem zachowania kultury muzycznej „Starej Rusi” przez zapomnieniem.

Reasumując, „Stara Ruś, jak słusznie zauważył W. Byczkow, srogo rozróżniała pojęcie śpiewu od pojęcia

\footnotetext{
${ }_{74} \mathrm{~W}$ jednym $\mathrm{z}$ listów Aleksego Michajłowicza adresowanych do metropolity nowogrodzkiego Nikona czytamy: „Да буди тебъ великому святителю въдомо: Многольтны у насъ поютъ вмъсто Патріарха: Спаси Господи, вселенскихъ Патріарховъ, и Митрополитовъ, и Архіепископовъ нашихъ, и вся Христіяне, Господи, Спаси; и ты отпиши къ намъ великій святителю, такъ ли надобъть пъть, или какъ инакъ пьть надобно, какъ у тебя святителя поютъ, и то отпиши къ намъ”. Cуt. za: Aктьы, собранные в библиотеках и архивах Российской Империи археографической экспедицией императорской академии наук, Санкт-Петерсбург 1836, T. IV, nr 57, s. 76.

75 С. Михайловский, Святейщий Никон, патриарх Всероссийский, Санкт-Петербург 1863, s. 58.

76 М. Зызыкин, Патриарх Никон..., Ч. 3, dz. суt., s. 210-211.

77 И. Вознесенский, Осмогласные роспевы..., dz. суt., s. 13

78 Tamże, s. 22.

79 В. Бычков, Русская средневековая эстетика XI-XVII века, Москва 1995, s. 402.

80 Н. Успенский, Древнерусское певческое искусство, Москва 1971,
} s. 318 . 
muzyki. Zrozumienie sensu obydwu terminów pozwoli lepiej zrozumieć sens owej walki „starego” z „nowym” w estetyce XVII wieku ${ }^{81}$. Wszystkie przemiany w śpiewie cerkiewnym, jakie dokonały się na przestrzeni XVII stulecia zmierzały do unifikacji staroruskiego śpiewu cerkiewnego. Powzięte zamiary staną się rzeczywistością dopiero w 2-giej połowie XVIII wieku, kiedy to z polecenia Świątobliwego Synodu wydano w Rosji pełen zestaw nutowych ksiąg, zawierający melodie znamiennogo raspiewa, pisane na pięciolinii opartą na wzorcach zachodnich notacją kwadratową ${ }^{82}$. Z perspektywy współczesności należy stwierdzić, iż kwestia chomonii nie dzieli już staroobrzędowców w takim stopniu,

\footnotetext{
81 В. Бычков, Эстетика в России XVII века, Москва 1989, s. 44

82 Drukarstwo muzyczne na użytek cerkiewny zostało zapoczątkowane w oficynach prowadzonych przez unicki zakon bazylianów. Pierwszym znanym cerkiewnym drukiem muzycznym był troparion Обятия Отча dołączony do niewielkiej objętościowo książki pt. Последование постригу (Profesja zakonna) wydanej w Supraślu w 1697 roku. Trzy lata później, nakładem unickiej drukarni zakonu bazylianów we Lwowie, ukazuje się Ирмолой сирпчь ппснословъ, kolejno wznawiany w 1709 i 1757 roku przez oficynę Bractwa Stauropigialnego we Lwowie, które przejęło od Bazylianów przywilej drukowania muzycznych ksiąg liturgicznych. Równocześnie druk śpiewników prowadziła oficyna Bazylianów w Poczajowie. - Zob.: M. Przywecka-Samecka, Dzieje drukarstwa w Polsce, Wrocław 1993, s. 205-213, por. M. Pidłypczak-Majerowicz, Bazylianie $w$ Koronie i na Litwie. Szkoły i książki $w$ działalności zakonu, Warszawa Wrocław 1986, s. 70-71.
}

jak miało to miejsce jeszcze sto lat temu. Niemniej jednak pewna konwencjonalizacja $\mathrm{w}$ podejściu do problematyki śpiewu, jaka dokonała się w kręgach staroobrzędowców na przestrzeni ostatnich dziesięcioleci, poniekąd zmusza nas do ponownego zadania pytania o sens utrzymywania tego typu „sakralnego znaku”83. Co do kwestii śpiewów wielogłosowych, punkt widzenia wyznawców „starej wiary” od wieków pozostaje niezmienny. Niemniej jednak staroobrzędowa liturgia w owym czasie dopuszczała wprowadzanie do użytku nowych, jednogłosowych melodii kijowskich bułgarskich i greckich. Zjawisko to dotyczy jedynie wspólnot staroobrzędowców uznających kapłaństwo - popowcó $^{84}$. Wiele $\mathrm{z}$ nich, mimo sprzeciwu konserwatywnych frakcji śpiewaków funkcjonuje w obiegu liturgicznym do dnia dzisiejszego.

83 Przejawem konwencjonalnego podejścia staroobrzędowców do problematyki śpiewu cerkiewnego było to, iż z czasem wykraczał on poza obręby świątyni. Coraz częściej był on słyszany na różnorakich koncertach, przez co stawał się bardziej dostępny i zrozumiały. - Zob.: Н. Денисов, Стрельниковский хор Костромской земли. Традиции старообрядческого иерковного пения, Москва 2005.

${ }_{84}$ Problem nowych melodii cerkiewnych obecnych w życiu liturgicznym staroobrzędowców był poruszany na licznych staroobrzędowych soborach oraz na łamach wydawanego na początku XX wieku w Kijowie czasopisma „Церковное Пение”. - Zob.: Е. Поспелов, О новыхъ напевахъ, [w:] „Церковное Пение”, 1909, nr 4-5, s. $92-98$.

\section{Bibliografia}

Awwakum, Żywot protopopa Awwakuma przez niego samego nakreślony i wybór innych pism, przeł. W. Jakubowski, WrocławWarszawa-Kraków-Gdańsk 1972

Encyklopedia muzyki, red. A. Stankiewicz, Warszawa 2001, s. 567.

Gołos J., Cerkiewny śpiew [w:] Encyklopedia Katolicka, T. III, kol. 1985, Lublin 1983, s. 19-21.

Iwaniec E., Z dziejów staroobrzędowców na ziemiach polskich XVII-XX w., Warszawa 1977.

Koschmieder E., Przyczynki do zagadnienia chomonji w hirmosach rosyjskich, Wilno 1932; Teoria i praktyka rosyjskiego śpiewu neumatycznego na tle tradycji staroobrzędowców wileńskich, „Ateneum Wileńskie”, 1935, R. 10, s. 295-305.

Łużny R., Staroobrzędowcy i problemy muzykologiczne Dawnej Rusi [w:] Musica Antiqua Europae Orientalis, T. VII, Bydgoszcz 1985, s. 83-96.

Pidłypczak-Majerowicz M., Bazylianie w Koronie i na Litwie. Szkoły i książki w działalności zakonu, Warszawa - Wrocław 1986.

Przywecka-Samecka M., Dzieje drukarstwa w Polsce, Wrocław 1993.

Sawicki D., Staroje istinnorieczije i razdielnorieczije jako dwie główne epoki w dziejach śpiewu liturgicznego na Rusi od XI w. do XVII w., [w:] Z badań nad językiem i kultura Stowian, red. P. Sotirov i P. Złotkowski, Lublin 2007, s. 169-178.

Sawicki D., Staroruski śpiew cerkiewny i funkcjonowanie jego wybranych form $w$ praktyce liturgicznej staroobrzędowców, Warszawa 2013 (rozprawa doktorska w ChAT)
Staroobrzędowcy, Encyklopedja Kościelna, T. XXIII, wyd. M. Nowodworski, Warszawa 1899, s. 38-43.

Wołosiuk W., Cerkiewny śpiew [w:] Religia - Encyklopedia, T. 2, Warszawa, red. nauk. T. Gadacz, B. Milerski, s. 396-398.

Wołosiuk W., Rozwój wschodniosłowiańskiej monodii cerkiewnej i jej zastosowanie w praktyce liturgicznej Polskiego Autokefalicznego Kościoła Prawosławnego - praca badawcza ChAT, Warszawa 2004.

Wołosiuk W., Śpiew liturgiczny Kościoła prawosławnego w Polsce: teologiczna i muzyczna interpretacja jego wybranych elementów, Warszawa 1996, (rozprawa doktorska w ChAT).

Wołosiuk W., Wschodniosłowiańscy kompozytorzy muzyki cerkiewnej od XVII do 1. połowy XX wieku i obecność ich utworów w nabożeństwach PAKP, Warszawa 2005.

Аввакум, Послание к некоей Маремяне Федоровне [w:] Материалы для истории раскола за первое время его существования, обр. Н. Субботин, Т. V, Москва 1879, s. 195200.

Аввакум, Послание к неизвестному лииу [w:] Материалы для истории раскола за первое время его существования, обр. Н. Субботин, Т. V, Москва 1879, s. 217-224.

Аввакум, Послание к священнику Стефану [w:] Материаль для истории раскола за первое время его существования, обр. Н. Субботин, Т. V, Москва 1879, s. 214-217.

Автобиограбия или житие протопопа Аввакума, tekst dostępny na: http://www.canto.ru/index.php?menu=public\&id= source.abbakum [02.03.2013]. 
Акты, собранные в библиотеках и архивах Российской Империи археограбической экспедицией императорской академии наук, Санкт-Петерсбург 1836, T. IV, nr 57, s. 76.

Антонович М., Українські співаки на Московщині в XVII cm. [w:] Mиsica Sacra. Збірнык статей з історії української иерковної музики, Львів 1997.

Артамонов Г., О хомовом пении, „Труды Киевской Духовной Академии", 1876, V. 1, 162-199.

Бороздин А., Протопопь Аввакум. Очеркъ истории умственной жизни русскаго общества въ XVII веке, Санкт-Петербург 1900.

Бражников М., Русская певческая палеография. Санкт-Петербург 2002.

Быстров С., Взглядб протопопа Аввакума на <хомовое> пение, „Церковное Пение”, 1909, nr 4-5, s. 135-139.

Бычков В., Русская средневековая эстетика XI-XVII века, Москва 1995.

Бычков В., Эстетика в России XVII века, Москва 1989.

Владышевская Т., Музыкальная культура Древней Руси, Москва 2006.

Вознесенский И., Осмогласные роспевы трех последних веков Православной Русской Церкви, Т. I, Киевский роспев, Киев, 1888.

Гарднер И., Богослужебное пение русской православной иеркви, Т. I-II, Москва 2004.

Денисов Н., Стрельниковский хор Костромской земли. Традииии старообрядческого иерковного пения, Москва 2005.

Зигабенъ Е., Толковая Псалтирь, Киев 1907.

Зызыкин М., Патриарх Никон. Его государственные и канонические идеи, Варшава 1931.

Каптерев Н., Патриарх Никон и иарь Алексей Михайлович, Т. І, Сергиев Посад 1909.

Коренев, Мусикия, РГБ, ф. 173. III, nr 154.

Кутузов Б., Церковная реформа XVII века, Москва 2004.

Макарий [М. Булгаков], История Русской Церкви, Т. ХI, Санкт-Петербург 1888.

Мезенец А., Извещение о согласнейших пометах, изд. Ст. Смоленский, Казань 1888.

Михайловский С., Святейший Никон, патриарх Всероссийский, Санкт-Петербург 1863.

Никольская Н., «Сказание» инока Евфросина и певческая книжная справа XVII века, Санкт-Петербург 2008.

Парфентьев Н., Древнерусское певческое искусство в ду- ховной культуре Российского Государства XVI-XVII вв., Свердловск 1991.

Поморские ответы, Москва 1911.

Поспелов Е., О новыхъ напевахъ, [w:] „Церковное Пение”, 1909, nr 4-5, s. 92- 98.

Преображенский А., Культовая музыка в России, Ленинград 1924.

Разумовский Д., О знаменном роспеве [w:] Круг иерковнаго древняго знаменнаго пения в шести частях. Иждивением потомственнаго почетнаго гражданина Арсения Ивановича Морозова, Санкт-Петербург 1884, Ч. І.

Разумовский Д., Церковное пение в России. Опыт историко-технического изложения, Москва 1867.

Сборник знаменных песнопений, включающий Азбуку знаменных песнопений, Москва 1984.

Смирнов В., Падение Третьего Рима. Духовные основы возрождения Русского Православного Царства, Санкт-Петербург 2008.

Смирнов П., Внутренние вопросы в расколе в XVII веке, Санкт-Петербург 1898.

Соболев Н., Мелодическое (одноголосное) пение Православной Русской Церкви, „Богословский Вестник”, Т. 3, nr 9.

Смоленский Ст., Примечания к азбуке Александра Мезениза, Казань 1888.

Стоглавъ, Санкт-Петербург 1997.

Толковая Библия или комментарии на все книги Св. писания Ветхого и Нового Завета, Петербург 1904-1913, изд. II, Стокгольм 1987.

Ундольский В., Замечания для истории церковного пения в России, Москва 1846.

Успенский Б., К вопросу о хомовом пении [w:] „Музыкальная культура средневековья”, Вып. 2, (Тезисы и доклады конференций), Москва 1991.

Успенский Б., Раскол и культурный конфликт XVII века [w:] Избранные Труды, Москва 1996, Т. I, s. 479-519.

Хомовое> или <наречное>, „Церковное Пение”, 1909, nr 8, s. 211-224.

Червякова Е., Традиции раздельноречного пения у старообрядцев поморского согласия [w:] Старообрядчество: история, культура, современность, Москва 2000, s. 486496.

Шушерин И., Известие о рождении и воспитании и житии святейшего Никона, патриарха Московского и всея России, Москва 1871. 